\title{
Fixed Phrases in Language of International Law: A Problem of Translating Latin Formulaic Expressions into Farsi
}

\author{
Seyed Mohammad Hossein Mirzadeh \\ Islamic Azad University, Iran \\ interprete3@gmail.com
}

\begin{abstract}
For the past twenty years, "phraseology" has been considered a very important topic of study for various specialized languages. The linguistic view that used to see phraseology such as "idiom researches and lexicography classifying various kinds of idiomatic expressions" has changed meaningfully. Nowadays, thanks to these changes, the new view is focused on identifying and classifying phraseology as well as applying them to research in theory. That is why we would do well to try to define new horizons of phraseology in different specialized languages. The language of interest here is the prescriptive and descriptive language of international law instruments. We should consider this language as the normative language of judges, legislators, courts and international lawyers. These practitioners - who use specific types of phraseology and stable linguistic structures -should perhaps adhere to the use of a professional language that conforms to recognized standards of normative rules. This paper, therefore, tries to define the main relations between phraseology studies and IL Latin expressions and their systematic-semantic equivalences in languages with different roots like Farsi.
\end{abstract}

Keywords: Phraseology, International Law Instruments, Latin Phrases and Expressions

\section{Introduction}

Despite all efforts, yet there are too important factors which should be studied about language of International Law. If we accept or not, the IL also enjoys a specific form of language which is made by a specific class of users in the societies. The users of this type of language are judges, lawyers, interpreters, courts, UN commissions and so forth which have a primordial role for defining the correct way to describe denotation-connotation of legal norms and rules. However, some important questions which arises here are that if we accept that language of IL has its own characteristics, how can we analyze and perceive it? Is it possible just to understand this type of language only by international legal knowledge? What about the other languages? Accepting that not all IL language users and makers are English or French speakers, how can the courts and 
international lawyers conclude documents that the other language users like Farsi or Arabic understand them well?

That's why we believe that we have to incorporate new data bases from the other sciences like linguistics, cognitive linguistics, and pragmatics and so forth into IL knowledge in order to be able to coding-decoding messages, statements and rules in international law. In this respect, one of the interdisciplinary studies which can help scholars to analyze correctly the sentences and expressions in international law could be phraseology or study of formulaic expressions. Enquiries about this type of knowledge show that it is necessary to evaluate IL formulaic expressions from this viewpoint specifically because of the existence of a huge number of Latin formulated expressions in that language. We believe that the study of phraseology and incorporating it into IL language, can help IL scholars to understand the real formulation-translation of these expressions used in international law.

We seriously believe that cognitive- corpus based linguistics could help International Lawyers to comprehend the main idea of expressions used in International Law Language part of which have been derived from Latin. In this aspect, a descriptive methodology can help reader or interlocutor of this paper to understand both, the main idea of this paper and know how to analyze this phenomena in his/her native language which in this specific case is Farsi since one of the biggest existing problems for Farsi speakers of IL texts is the huge vague or etymological- cognitive differences between Farsi and Latin.

For all above mentioned reasons, the aim of this paper is to evaluate the impact of some phraseological studies and enquiries in forming- translating International Law Latin formulaic expressions and the objective equivalences in the other languages like Farsi, a language that has nothing to do with Latin languages in any linguistic and extra linguistic aspect, responding to this important question that have systematic differences of Latin Legal language to do with semantic phase when translating IL Latin expression into Farsi or not? That is why we will try to show, at first hand, some useful IL Latin expressions and at second one, evaluate their systematic- translational equivalences in Farsi.

\section{The Latin phraseological Units in IL texts}

It seems to be a challenge analyzing and speaking about phraseology because the interlocutor of learner probably encounter it really confusing with the other aspects of cognitive linguistics, applied linguistics and discourse analysis [16]. According to Cowie, there is a lack of standardized terminology [6]. That is to say, there exist terminologies like collocations or idioms which referred for decades to the same idea of phraseological units. That's why we could declare that for having an uncertain terminology about the phenomena, so the final decision about what the identity is comes really difficult.

We believe that these stable and fixed phrases in IL have their own grammatical, discursive and semantic characteristics. For instance, when the ICJ or international lawyers use expressions of phraseological units like: utti posidetti juris, jus gentium, ex aequo et bonno, jus cogens, erga omnes and etc. there is going to emerge an idea of figurative language in particular interlocutors regarding the content of the discourse and 
the usage of these types of legal expressions. "jus cogens", being a type of phraseological fixed and stable unit which could be studied from different points of view, should be interpreted in a narrative way in order to connate in the strict manner :"promtory or imperative norms" or قواعد آمره An international judge or lawyer by this unit, has a clear intention which is to call the attention of specialized interlocutor: 1- this comes from a Latin legal system which has been used during years and it is working like an international norm which is applicable for all of the IL subjects 2- in a grammatical approach, it is formed by 2 parts (monems or signifiers) which connate an action or reaction: "these norms or Jus are to be considered important and binding that the violation of them could not be presumed."

\section{Translating some IL Latin formulaic units into Farsi}

Translation of specialized texts, especially legal terms, is not as easy as some people think; it not only requires stylistic competence in the language, but it also requires knowledge of the inner meaning and connotation of words of the legal systems. That is why Farsi translators and then, interpreters of legal terms especially Latin ones, should be aware of both stylistic and phraseological features of these terms and semantic and connotative characteristics in order to get the right sense. For instance, there is no any literal meaning for Ex aequo et bonno term (phraseological unit) in Farsi but the translators are obliged to explain It in other words which could lead to descend the principal denotation of the term. For instance, the word Jus when is used with ad bellum has a specific connotation and equivalence in Farsi and when it is used with Cogens, has a stricter meaning regarding imperative norms of IL. The other useful example is when we use Jus with Gentium, when the meaning differ from the previous ones and it is transferred like "rights and demands of people". The below Examples Show that it is almost impossible to preserve grammatical density, phraseological characteristics of Latin language and semantic properties while translating them into Farsi:

Utti Possidetti Juris: تبديل مرزهاى حين استعمار به مرزهاى بعد از استقلال Eng.: As You Possess

Ex aequo et bonno: $\quad$ Eng.: According to

the Right and Good

Lex fori: قانون مقر دادكاه $\quad$ Eng.: the Local

Law

Jus Cogens: $\quad$ قواعد آمره $\quad$ Eng.: Imperative

Norms

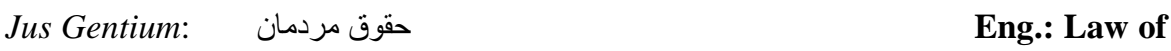

Nations

\section{Concluding remarks}

The objective of this paper was to propose the design a systematized view for encoding and describing phraseological information in IL language and to create a new aspect of fixed legal terms especially those which come from Latin. 
Difference in language systems could lead differences in translational phase. For instance, Jus is sometimes translated like حقوق which is "law" in English and sometimes is translated like قواعد which is "norms or rules" in English. The systematic and semantic nature of Jus in Latin is the same but while translating it into Farsi, it changes from context to another context. That's why it can be inferred that the "contextual criteria" of the target languages like Farsi has also to do with the exact meaning of IL Latin formulaic expressions.

As studied above, the systematic- etymologic differences between languages like Farsi and Latin especially in specialized areas like IL could result in different ways of translating expressions. Another clear example in this aspect is Utti Possidetti Juris which is a 3 words expression while its literal translation in Farsi does not exist so the Farsi lawyers translate it like: تببيل مرزهاى حين استعدار به مرزهاى بِ /ز /ستقلال So it is translated in a completely contextual manner in order to show the exact connotative meaning.

The underlying idea is that when translating phraseological IL units from Latin languages into Farsi, it is particularly difficult to adequately convey an equivalence that connotes the same root, lexeme and sense of terms. Therefore, to understand the main ideas and connotations of these phraseological units, the Farsi interlocutors should use a triangular approach: 1) perception of denotative-connotative meaning, 2) analysis, and finally 3 ) expression of the main idea of the terms if there is not any literal equivalence, especially for units like: ex aequo et bonno, utti posidetti juris and the expressions with more than one word, signifier and connotation.

\section{References}

1. Cowie, A.P. The treatment of collocations and idioms in learners dictionaries, applied linguistics 2 (3): 223-235 (1981)

2. Cowie, A.P. "Introduction". In Cowie, A.P. Phraseology. Theory, Analysis, and Applications, 1-20, Oxford: Clarendon Press (1998)

3. Moon, R. Textual aspects of fixed expressions in learner's dictionaries. In Vocabulary and Applied Linguistics, P.J.L. Arnaud \&Bejoint (eds), 13-27. London: Macmillan (1992) 